\title{
21-YEAR DYNAMICS OF MARINE BENTHIC CILIATE COMMUNITY IN THE WHITE SEA INTERTIDAL FLAT: GRADUAL OR DISCRETE?
}

\author{
I. V. Burkovsky \\ Lomonosov Moscow State University, 1 Leninskiye Gory, Moscow, 119899, Russia \\ E-mail: burkovsky_i@mail.ru
}

\section{Yu. A. Mazei}

Lomonosov Moscow State University, 1 Leninskiye Gory, Moscow, 119899, Russia

Penza State University, 40 Krasnaya str., Penza, 440026, Russia

E-mail: yurimazei@mail.ru

\section{АИНАМИКА СООБЩЕСТВА ИНФУЗОРИЙ НА ЛИТОРАЛИ БЕЛОГО МОРЯ ЗА 21-ЛЕТНИЙ ПЕРИОА: КОНТИНУАЛЬНОСТЬ ИЛИ АИСКРЕТНОСТЬ?}

\section{И. В. Бурковский}

Московский государственный университет имени М. В. Ломоносова, Россия, 119899, г. Москва, Ленинские горы, 1 E-mail: burkovsky_@mail.ru

\section{Ю. А. Мазей}

Московский государственный университет имени М. В. Ломоносова, Россия, 119899, г. Москва, Ленинские горы, 1 Пензенский государственный университет, Россия, 440026, г. Пенза, ул. Красная, 40

E-mail: yurimazei@mail.ru

Abstract. Changes in the composition, structure and seasonal succession patterns were observed in a local community of interstitial ciliates over a period of 21 years (1991-2011). General trends in species structure transformation were revealed. During 1991-2004 years Trachelocerca incaudata, Remanella margaritifera, Coleps tesselatus, and Uronema marina, dominated in the community. However, in 2005-2011 the number of specific interstitial ciliate species, and of Apotrachelocerca arenicola in particular, increased considerably. These changes were caused by the increase in the silt content in the sediments. Long-term changes were realized at different stages of seasonal development of the community including both, more structurally simple earlier period (in the beginning of spring) and more structurally complex mature period (at the end of summer). The most mature state of ciliate community was temporally (in the inter-year scale) stable, but discretely (drastically) transformed from one variant (in 1991-2004) to another one (in 2005-2011). The simpler state of ciliate community was more variable between years and transformed gradually from one polymorphic variant (in 1991-1995, 1998, 2000-2005, 2009-2010) to another one (in 2006-2008, 2011). This suggests that discrete and stable mature communities can be assembled via different annual trajectories.

Key words: ciliates, community, long-term dynamics, White Sea, intertidal flat.

For citation: Burkovsky I.V., Mazei Yu.A. 21-year dynamics of marine benthic ciliate community in the White sea intertidal flat: gradual or discrete? Russian Journal of Ecosystem Ecology. 2017;2(2). Available from: https://doi.org/10.21685/2500-0578-2017-2-1

Аннотация. Исследовали изменения видового состава, структуры и хода сезонной сукцессии локального сообщества интерстициальных инфузорий литорали Белого моря за 21-летний период (1991-2011 гг.). Описаны общие тенденции изменения видовой структуры сообщества. В течение 1991-2004 гг. доминировали Trachelocerca incaudata, Remanella margaritifera, Coleps tesselatus и Uronema marina. Однако в 2005-2011 гг. количество специфических интерстициальных видов и в особенности Apotrachelocerca arenicola существенно возросло. Эти изменения обусловлены возрастанием заиленности донных осадков. Долговременные изменения сообщества проявляются на разных стадиях сезонной сукцессии, включая структурно более простые ранние стадии (в начале весны) и более структурно сложные поздние стадии (в конце лета). Наиболее зрелое позднелетнее состояние сообщества инфузорий стабильно в разные годы и дискретно трансформируется из одного варианта (в 1991-2004 гг.) в другой (в 2005-2011 гг.). Более простое состояние сообщества инфузорий более изменчиво в разные годы и постепенно превращается из одного полиморфного варианта (в 1991-1995, 1998, 2000-2005, 2009-2010 гг.) в другой (в 2006-2008, 2011 гг.). Это означает, что дискретные и стабильные зрелые позднелетние варианты сообществ могут формироваться по разным сезонным траекториям.

Ключевые слова: инфузории, сообщества, многолетняя динамика, Белое море, литораль. 


\section{Introduction}

Time forms convenient dimension upon which to classify natural phenomena, ranging from the diurnal migration of organisms, the seasonal changes of communities, the climatic shifts of the Quaternary to the mass extinctions recorded in the deep geological record. The types of drivers that impact the ecosystems can be arranged on a temporal scale [18]. Among them decadal shifts including geological stochastic events, which cause long-term shifts in community structure and abundance, are less known. At the same time studies of such decadal processes, embracing the replacement of thousands of generations could provide important information on temporal organization and stability of communities in a fluctuating environment.

Several drivers are distinguished as affecting long-term (decadal) processes in marine environment. Studies in the Baltic Sea revealed the basic trends of zooplankton community variations depending on oceanographic processes. Alternation of the periods of increase and decrease in salinity of the Baltic Sea against the background of climate changes (temperature increase) and eutrophication affect the state of zooplankton communities [1]. Climate change affects phytoplankton community dynamics in the Western English Channel [45]. The hydrographical regime as well as potential impact of eutrophication on the oxygen balance of the deep waters has high significance in predicting distribution of macrofauna in the Eastern Gotland Basin and the Gulf of Finland [28]. Variation of salinity the Vaccarès lagoon (the Mediterranean Sea) lead to the increased and decreased patterns of freshwater species and some marine species in fish and macro-crustacean community [37]. Changes in the sediment siltation shape meiobenthic community structure with relation of the dominant groups in nematodes and harpacticoid copepods $[15,21]$. Climatic shifts as well as anthropogenic oligotrophication cause the changes of the seasonal dynamics of microzooplankton abundance and the tintinnids composition in the North Adriatic [34].

Most of such surveys deal with the explanations on below community hierarchical levels (populations). However recently the importance of community approach in long-term studies was discussed [29]. Obviously, in this reason, the most appropriate objects are tiny, quickly reproducing organisms. Among such communities, those of marine littoral interstitial ciliates are distinguished by having a very high biodiversity and abundance, and also by the possibility of regular and long-term observations $[2,16,36]$. Yet long-term changes in protozoan communities during time periods measuring thousands of generations have never been a subject of special investigations.
Besides, marine interstitial ciliate communities are characterized by prominent annual cycles that are caused by dynamics of temperature, illumination, available food resources and interspecific interactions. Psammophilous ciliate community is considerably changed in the course of the year: from a reduced, simple and weakly structured community in the end of the hydrological winter (April) towards a complex, multispecies, highly spatially heterogeneous system in the end of the summer season (August-September) $[3,5,6]$. How do these annual stages of a community transform in course of decades?

The aim of this study was to describe decadal dynamics of marine benthic ciliate community in order to understand, whether community transformation is gradual (continual) or discrete (drastic) and to reveal, whether different stages of annual succession have different responses to the longterm environmental modifications occurred during 1991-2011. This paper is based on our previous investigations concerning long-term dynamics of marine ciliate community, where we aimed to reveal the trends, amplitude and periodicity of community structure fluctuations over 1991-2008 [9-11] as well as to indicate dynamics of species populations $[12,44]$.

\section{Material and methods}

Investigations were conducted on a small area (1 square meter) of sandy beach located on the border between the low and the middle littoral in the Gryaznaya Bay (the Kandalaksha Gulf, the White Sea) from 1991 to 2011 (Fig. 1). This is one of the White Sea long-term monitoring points placed near the Lomonosov Moscow State University White Sea Biological Station [40]. Sampling was performed every week from May to September (in 2001 also in January, February and April) during low water. Fifteen samples were taken with the aid of a glass tube (with a cross-section area of $1 \mathrm{~cm}^{2}$ ) penetrated into the sand down to the depth of $3 \mathrm{~cm}$, which resulted in a $45 \mathrm{~cm}^{3}$ total sample. In the laboratory, the ciliates from the total $45 \mathrm{~cm}^{3}$ sample were washed from the sand according to the Uhlig method [41] within one hour after sampling. The ciliates were counted in a living state under the stereomicroscope BIOMED-9 (Russia) at a magnification of $\times 32-56$. One fifteenth part of the total sample was microscopically analyzed $[8,33]$. Several abiotic factors were measured at the sampling sites: vertical profile of Eh within the sediments (allow to estimate the depth of the aerobic layer and indirectly to approximate the depth of photic zone), $\mathrm{pH}$, the silt content in sediments, salinity and temperature of air and water, light intensity in the top $1 \mathrm{~cm}$ sediment layer. 


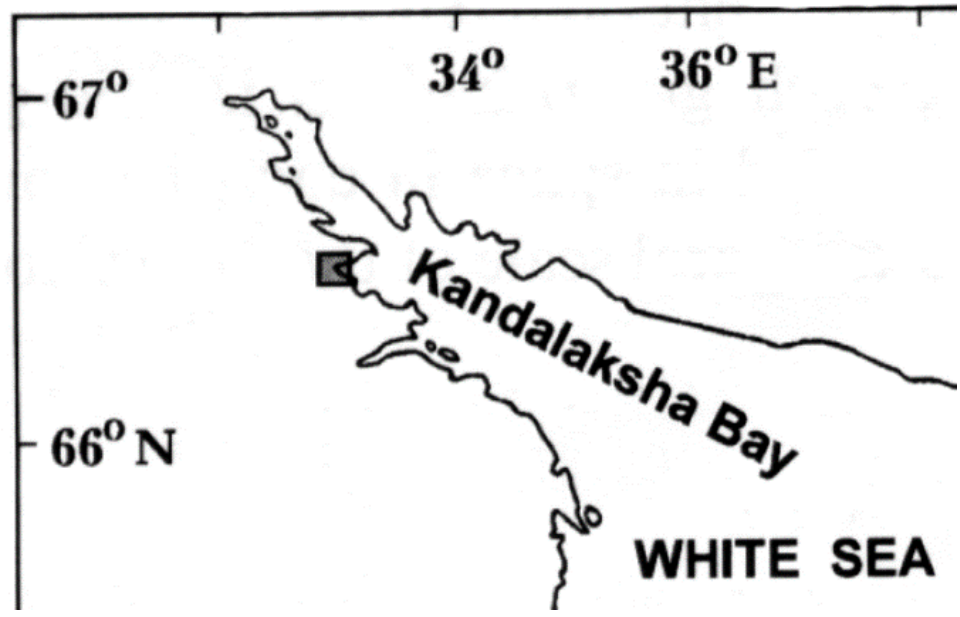

Fig. 1. Area of investigation

Group average cluster analysis based on the Bray-Curtis similarity index of species relative abundances matrix was performed to classify communities in course of 1991-2011. The reliability of grouping was assessed at the level $p<0.05$, using SIMPROF algorithm [14]. Principal component analysis was applied in order to relate community changes with species composition of dominants. Calculations were made with the use of PAST 2.08 [20] and PRIMER [14] packages.

\section{Results}

\section{Biotope characteristics}

The main tendency of the long-term changes in the Bay is the reduction of the space covered with pure sand and the replacement of sandy sites by silty sediments. The space covered with macrovegetation (graminoids with tussocks on saline marsh on the upper intertidal flat, Zostera marina on the lower intertidal flat) has increased, which resulted in siltation and compression of the sediments [7]. In the period from 1991 to 2011 an increasing amount of silt within the sediments was noted (from 4-6 to 20-35\%). The process of silt accumulation was the most intensive during the last decades. Thus, in 1978-1990 (before the collection of material for this study was started) the amount of silt was less than 2-3\% [3]; in 1993, it was 5-10\%, and in 2008-2011, 20-30\%. The level of Eh in the upper $0.5 \mathrm{~cm}$ sediment layer was within the limits $+200 \ldots+250 \mathrm{mV}$ before 1993 , and $+50 \ldots+100 \mathrm{mV}$ in $2006-2011$. The depth of the aerobic layer, where most of the microbenthic organisms dwell, decreased in the same direction. In 1991 the depth of the aerobic layer reached 3-4 cm, while in 2006-2011 it did not exceed $0.5-1.0 \mathrm{~cm}$. As a result, the living space for oxiphylic organisms (more than $95 \%$ of psammophilous ciliates are oxyphilic) declined several times during the last 21 years. Moreover, in the last years a thin layer of silt covering the sediments developed, decreasing the penetrability of sediments for light and hampering water-exchange. The photic zone descended from $2.0-2.5 \mathrm{~mm}$ in 1991-1993 to 0-1 mm in 2006-2011, which affected the composition and productivity of microphytobenthos (dinoflagellates and diatoms), the main food for ciliates. Changes of temperature during this period were not so directed. The years with maximal temperatures within the summer season $(1993,1994$, 2005, 2010: $12.1-13.7{ }^{\circ} \mathrm{C}$ ) alternated with colder years $\left(1995,1998,2000\right.$ : $\left.10.1-10.8^{\circ} \mathrm{C}\right)$. Salinity had no significant trends varying in August from 22 to $24 \%$ in different years.

\section{General long-term pattern of the ciliate community composition and structure}

In 1991-2011, on the area of 1 square meter 125 ciliate species were identified $(85 \%$ from the total checklist of ciliates discovered in the Gryaznaya Bay during the last 30 years - [32]). Each year on the average 81 species occurred in the community (52-92 species in different years). In a single sample $(15 \times 15 \times 3 \mathrm{~cm}$ in size $)$, the average of 47 species were recorded in different months (15-70 species in different years).

The set of the most abundant species (with average annual abundance exceeding $5 \%$ at least in one year) was represented by 14 species (Table 1). The most abundant species were Remanella margaritifera, Apotrachelocerca arenicola, Trachelocerca incaudata, Coleps tesselatus, Histiobalantium marinum, Uronema marina. The community showed a clear trend from polymixic to oligomixic state: while in 1991-2002 more than 50\% of the total abundance was formed by 5-7 species, in 2003-2005 the corresponding number of species was 3-4, and in 2006-2011, 1-2 species. 
$\frac{\check{1}}{\frac{\pi}{0}}$

\begin{tabular}{|c|c|c|c|c|c|c|c|c|c|c|c|c|c|c|c|c|c|c|c|c|c|c|c|}
\hline I I0Z & $\begin{array}{c}\sim \\
\\
\sim\end{array}$ & 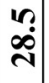 & शे & $\begin{array}{l}0 \\
\text { तi }\end{array}$ & ro & $m$ & 工 & $\infty$ & $\stackrel{m}{0}$ & $\begin{array}{l}0 \\
0\end{array}$ & $\stackrel{m}{n}$ & $\stackrel{\sim}{-}$ & $\begin{array}{l}0 \\
\dot{0}\end{array}$ & ㅇ. & $\dot{0}$ & 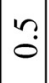 & $\underset{-}{\infty}$ & $\stackrel{+}{-}$ & $\stackrel{9}{-}$ & $\tilde{o}$ & $\overrightarrow{0}$ & 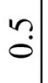 & $\overrightarrow{0}$ \\
\hline 0I0Z & 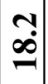 & $\stackrel{m}{\stackrel{m}{\sim}}$ & $\stackrel{\infty}{-}$ & ָָ & $\left|\begin{array}{l}\infty \\
\alpha \\
\sigma\end{array}\right|$ & 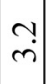 & $\begin{array}{l}\infty \\
i\end{array}$ & r̦ & $\ddot{0}$ & $\overrightarrow{0}$ & $\stackrel{n}{n}$ & $\stackrel{\infty}{0}$ & $\begin{array}{l}\infty \\
0 \\
0\end{array}$ & $\stackrel{0}{0}$ & $?$ & $\vec{r}$ & $\begin{array}{l}0 \\
\dot{r}\end{array}$ & તָ & $\exists$ & $\begin{array}{l}\infty \\
0 \\
0\end{array}$ & $\stackrel{0}{0}$ & $\stackrel{\nabla}{-}$ & $\stackrel{0}{0}$ \\
\hline $600 z$ & 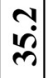 & $\begin{array}{l}0 \\
\vec{N}\end{array}$ & $\stackrel{\nabla}{-}$ & $\stackrel{?}{-}$ & 8 & $\because$ & $\overrightarrow{\mathrm{i}}$ & à & $\stackrel{0}{0}$ & $\stackrel{0}{0}$ & 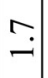 & $\dot{0}$ & $\begin{array}{l}0 \\
\dot{0}\end{array}$ & $\overrightarrow{0}$ & ָ̦ & $\stackrel{0}{-}$ & $\begin{array}{l}0 \\
0 \\
0\end{array}$ & $\stackrel{\nabla}{-}$ & ִָ & $\stackrel{+}{0}$ & $\exists$ & 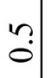 & $\overrightarrow{0}$ \\
\hline $800 z$ & $\stackrel{\dot{m}}{\vec{m}}$ & m̊. & $\hat{\theta}$ & בִ & $\underset{+}{+}$ & $\stackrel{\sim}{-}$ & $\stackrel{\theta}{\hat{\theta}}$ & $\stackrel{+}{\circ}$ & $\stackrel{0}{0}$ & $\overrightarrow{0}$ & $\begin{array}{l}0 \\
0 \\
0\end{array}$ & $\stackrel{+}{\circ}$ & $\begin{array}{l}0 \\
0 \\
0\end{array}$ & $\stackrel{\infty}{0}$ & $\overrightarrow{0}$ & $\hat{0}$ & $\stackrel{+}{\circ}$ & Iִ & $\dot{r}$ & $?$ & ?? & $\begin{array}{l}+ \\
\mathrm{i}\end{array}$ & $\overrightarrow{0}$ \\
\hline$\angle 00 Z$ & $\begin{array}{l}\infty \\
\dot{j} \\
\dot{J}\end{array}$ & 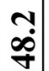 & 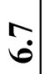 & $\stackrel{\nabla}{-}$ & in & 0 & $\begin{array}{l}10 \\
0 \\
100\end{array}$ & 9. & $\stackrel{0}{0}$ & $\stackrel{\Upsilon}{0}$ & $\stackrel{+}{0}$ & $\stackrel{?}{0}$ & 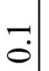 & $\begin{array}{l}\infty \\
i\end{array}$ & $\overrightarrow{0}$ & $\left|\begin{array}{c}\infty \\
i\end{array}\right|$ & 임. & $\ddot{0}$ & : & ֻே & $\stackrel{0}{0}$ & $\overrightarrow{0}$ & $\stackrel{0}{0}$ \\
\hline $900 z$ & $\stackrel{m}{\simeq}$ & $\begin{array}{c}0 \\
m \\
m\end{array}$ & 范 & $\vec{\sim}$ & ì & $\begin{array}{l}0 \\
\dot{0}\end{array}$ & $\vec{m}$ & $\begin{array}{l}0 \\
\dot{0}\end{array}$ & $\begin{array}{l}0 \\
0\end{array}$ & $\begin{array}{l}\infty \\
\dot{0}\end{array}$ & $\stackrel{m}{0}$ & $\stackrel{m}{0}$ & $\begin{array}{l}0 \\
0\end{array}$ & $\stackrel{+}{-}$ & $\stackrel{n}{0}$ & $\hat{\sigma}$ & $\begin{array}{c}\infty \\
\dot{m}\end{array}$ & 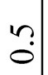 & $\stackrel{m}{-}$ & $\begin{array}{l}\infty \\
0\end{array}$ & $\begin{array}{l}0 \\
0\end{array}$ & ִֻ & $\stackrel{0}{0}$ \\
\hline$\varsigma_{00 Z}$ & $\stackrel{9}{\dot{j}}$ & $\stackrel{?}{a}$ & $\stackrel{n}{ \pm}$ & $\underset{\nabla}{-1}$ & $\stackrel{?}{=}$ & $\begin{array}{l}n \\
n \\
\dot{n}\end{array} \mid$ & $\begin{array}{l}\infty \\
\dot{r}\end{array}$ & $\begin{array}{l}0 \\
i \\
\sim\end{array} \mid$ & $\stackrel{0}{0}$ & $\stackrel{?}{0}$ & $\stackrel{n}{0}$ & $\stackrel{?}{0}$ & ?? & $\stackrel{\nabla}{r}$ & $\stackrel{n}{0}$ & $\hat{0}$ & $\Rightarrow$ & $\stackrel{\nabla}{-}$ & $\stackrel{?}{-}$ & $\tilde{o}$ & $\stackrel{\Upsilon}{0}$ & $?$ & $\stackrel{\Upsilon}{0}$ \\
\hline$t 00 z$ & $\stackrel{9}{ \pm}$ & $\dot{r}$ & $\stackrel{9}{ \pm}$ & $\stackrel{m}{\sim}$ & $\mid \begin{array}{l}\infty \\
\alpha \\
\alpha\end{array}$ & $\stackrel{?}{=}$ & 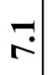 & $\begin{array}{c}0 \\
\text { ci }\end{array}$ & $\stackrel{0}{0}$ & $\begin{array}{l}\infty \\
\dot{0}\end{array}$ & $\overrightarrow{0}$ & $\exists$ & $\stackrel{+}{\circ}$ & $\begin{array}{c}0 \\
\text { ले }\end{array}$ & $\overrightarrow{0}$ & $\dot{0}$ & $\begin{array}{l}\infty \\
0\end{array}$ & ָָ & $\underset{-}{0}$ & $\stackrel{+}{-}$ & '? & $\stackrel{0}{-}$ & $n$ \\
\hline$\varepsilon 00 Z$ & $\begin{array}{l}0 \\
0 \\
0\end{array}$ & בִ & ఫें & $\stackrel{n}{n}$ & $\overline{\dot{\theta}}$ & $\Xi$ & 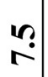 & $\stackrel{\nabla}{\sim}$ & $\stackrel{n}{0}$ & 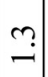 & $\stackrel{\infty}{-}$ & 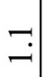 & $\stackrel{\nabla}{\circ}$ & $\begin{array}{l}\infty \\
i\end{array}$ & $?$ & $\begin{array}{l}\infty \\
0\end{array}$ & $\stackrel{0}{-}$ & $\overrightarrow{\mathrm{i}}$ & $\begin{array}{l}0 \\
0\end{array}$ & 二 & $\dot{0}$ & $\stackrel{N}{N}$ & $0 ?$ \\
\hline $200 Z$ & $\begin{array}{l}9 \\
\underline{10}\end{array}$ & $\vec{m}$ & ले. & in & $\stackrel{+}{\infty}$ & $\because$ & $\underset{\nabla}{+}$ & à & $\stackrel{0}{-}$ & ণi & $\dot{r}$ & ç & $\stackrel{0}{0}$ & $\overrightarrow{\mathrm{i}}$ & $\overrightarrow{\mathrm{i}}$ & $\stackrel{\nabla}{\circ}$ & $\stackrel{\nabla}{-}$ & $\begin{array}{l}0 \\
\text { i }\end{array}$ & ○. & $\stackrel{0}{0}$ & ? & ra & $\stackrel{?}{0}$ \\
\hline
\end{tabular}

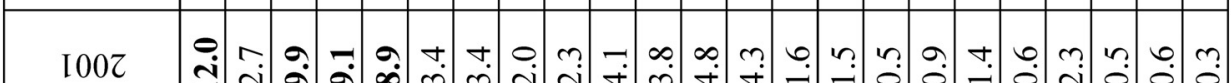

\begin{tabular}{|c|c|c|}
\hline$J 0 \mathrm{C}$ & N & \\
\hline
\end{tabular}

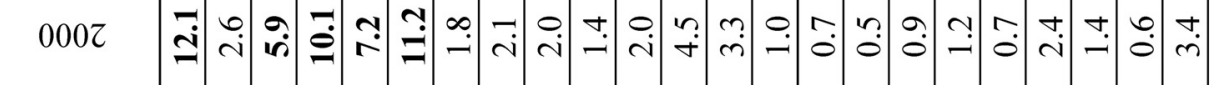

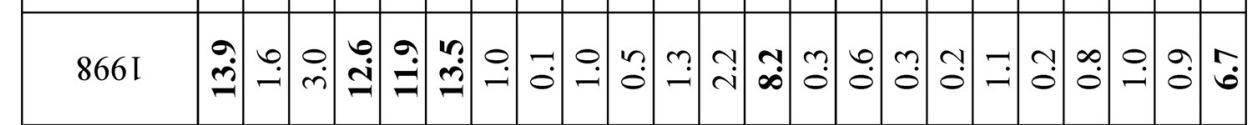

\begin{tabular}{|c|c|c|c|c|c|c|c|c|c|c|c|c|c|c|c|c|c|c|c|c|c|}
\hline$\varsigma 66 \mathrm{I}$ & 苛 & $\stackrel{m}{\sim}$ & : & $\stackrel{0}{0}$ & 'n? & $\begin{array}{l}0 \\
\dot{m}\end{array}$ & $\stackrel{?}{\sim}$ & శై & ras & \begin{tabular}{ccc}
0 & \multirow{2}{c}{} \\
$\dot{m}$ & 0
\end{tabular} & \begin{tabular}{c|c} 
ris \\
\multirow{2}{*}{}
\end{tabular} & & & & $\begin{array}{l}+ \\
+i\end{array}$ & 二 & $\ddot{0}$ & 0 & n': & $?$ & ث. \\
\hline t66I & $\underset{\forall}{\nabla}$ & $\stackrel{\nabla}{-}$ & 2 & 尺ें & $\begin{array}{l}0 \\
\stackrel{i}{1}\end{array}$ & (ָ) & $\stackrel{n}{i}$ & 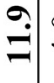 & $\stackrel{\circ}{+}$ & $\begin{array}{l}\infty \\
\dot{\nabla}\end{array}$ & $\stackrel{-}{-}$ & तi & \begin{tabular}{ccc}
0 & \multicolumn{1}{c}{} \\
$m$ &
\end{tabular} & $\because$ & \begin{tabular}{l|l}
$\infty$ & 0 \\
0 & 0
\end{tabular} & $\dot{0}$ & $\begin{array}{l}0 \\
0\end{array}$ & $\begin{array}{ll}0 \\
0\end{array}$ & & $=\stackrel{0}{0}$ & 0 \\
\hline
\end{tabular}

\begin{tabular}{|c|c|c|c|c|c|c|c|c|c|c|c|c|c|c|c|c|c|c|c|c|c|}
\hline E66 I & 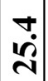 & $\dot{m}$ & iv & $\therefore$ & 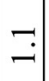 & $\stackrel{m}{m}$ & $\begin{array}{l}\infty \\
\stackrel{i}{ }\end{array}$ & $\vec{i}$ & हे. & $\stackrel{g}{\dot{f}}$ & $\stackrel{ナ}{\sim}$ & $\stackrel{n}{-}$. & $\stackrel{\nabla}{-}$ & $\begin{array}{l}0 \\
\dot{1}\end{array}$ & $\underset{1}{e}$ & \begin{tabular}{ll|l}
0 \\
\end{tabular} & $\ddot{0}$ & $?$ & \begin{tabular}{l|l}
0 & $\infty$ \\
$i$ & 0
\end{tabular} & $\stackrel{\infty}{\circ}$ & 苛 \\
\hline Z66I & $\begin{array}{l}n \\
n \\
n\end{array}$ & $\vec{m}$ & $\stackrel{\nabla}{\stackrel{\bullet}{\varrho}}$ & 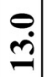 & $\stackrel{m}{\sim}$ & $\stackrel{?}{\nabla}$ & ชิ & $\begin{array}{l}0 \\
0 \\
0\end{array}$ & $\overrightarrow{\mathrm{i}}$ & $n$ & $?$ & 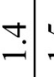 & '? & $\ddot{0}: 气$ & $\begin{array}{ccc}\mathrm{r} & \mathrm{r} \\
\mathrm{i} & \mathrm{s}\end{array}$ & $\dot{0}=$ & $\begin{array}{l}\infty \\
0 \\
0\end{array}$ & $\stackrel{\nabla}{\nabla_{0}}$ & $\stackrel{n}{2}$ & $\begin{array}{l}\vec{i} \\
\dot{\mathrm{O}}\end{array}$ & $\begin{array}{l}\vec{t} \\
\mathrm{i}\end{array}$ \\
\hline I66 I & ra & $\dot{r}$ & $\vec{i}$ & 官 & $\stackrel{m}{i}$ & $\ddot{a}$ & $\underset{.}{\infty}$ & $\stackrel{.}{0}$ & $\ddot{q}$ & $\dot{0}$ & ले| & . & $\stackrel{+}{\circ}$ & $\Rightarrow$ & $\underset{i}{+}$ & : & $\stackrel{m}{-}$ & $\dot{0}$ & $\underset{c}{\sim}$ & بـ & 趿 \\
\hline
\end{tabular}

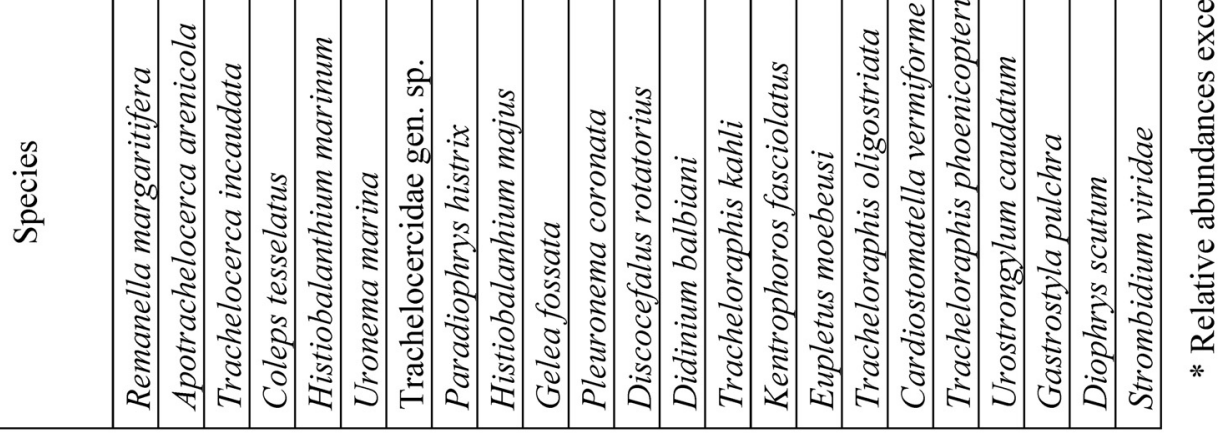


The result of community classification (Fig. 2) show that two major groups are distinguished corresponding to earlier (1991-2005) and later (20062011) stages of the investigation. In total, seven significant clusters are separated uniting the periods of 1991-1995, 1998, 2000-2001, 2002, 2003-2005, and 2006-2008, 2009-2011 years, respectively. The grouping reflects existence of general trend in species structure transformation. The results of community ordination show that more than $70 \%$ of the total community variance (along the first principal component) is associated with the differences between the 2005-2011 assemblages and the others (Fig. 3) i.e. reflected trended (but not accidental!) changes of species abundances. Since 2005 dominants Remanella margaritifera and Trachelocerca incaudata as well as subdominants Coleps tesselatus and Uronema marina ceded their place to Apotrachelocerca arenicola. The rest of the variance (along the second principal component) is associated with the inter-annual fluctuations in the period from 1991 to 2004. Two community variants are the most prominent during this period: 1) with dominants Trachelocerca incaudata and Coleps tesselatus in 1994 and 1995, and 2) with dominant Remanella margaritifera in 1991, 1993 and 2009.

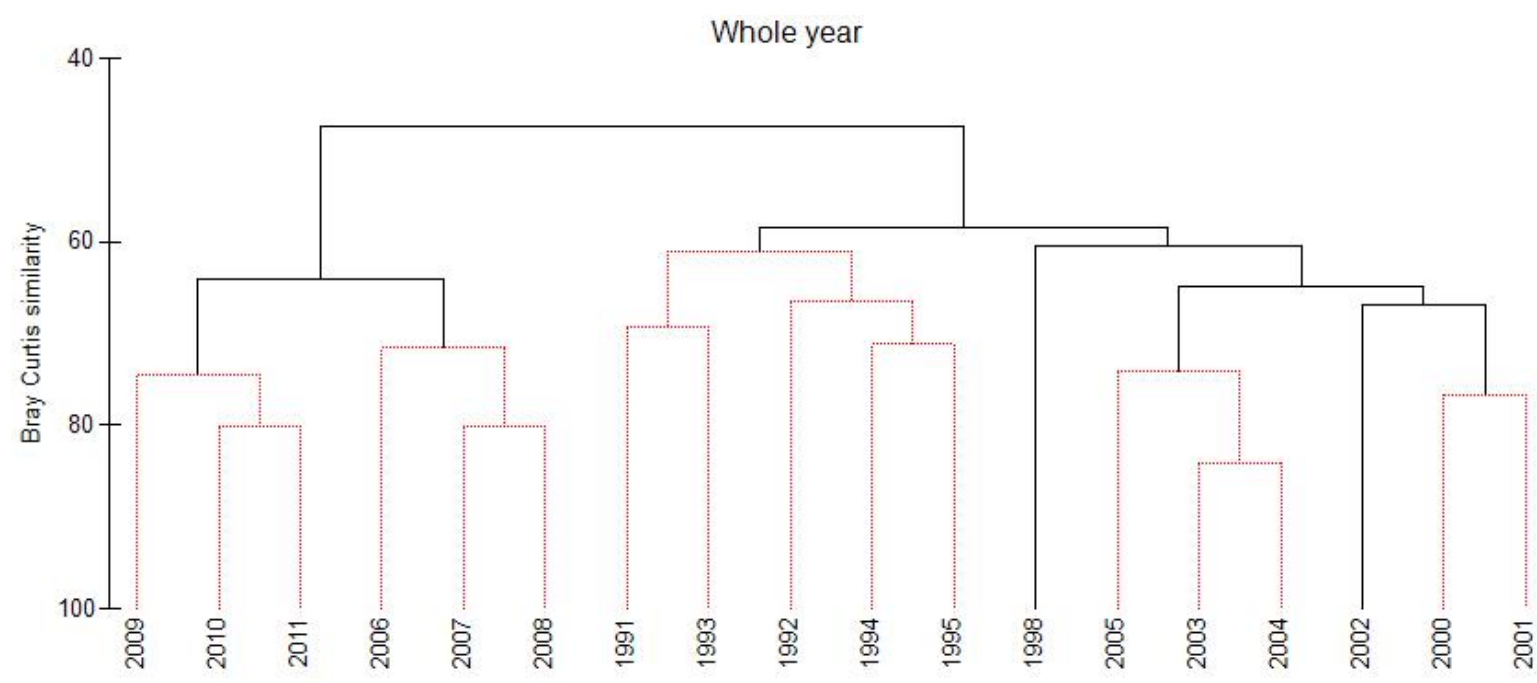

Fig. 2. Community classification by cluster analysis based on relative abundances of all species in the community (average for annual period). The significantly different groups are separated by black solid lines, and the insignificantly different groups are separated by red dashed lines

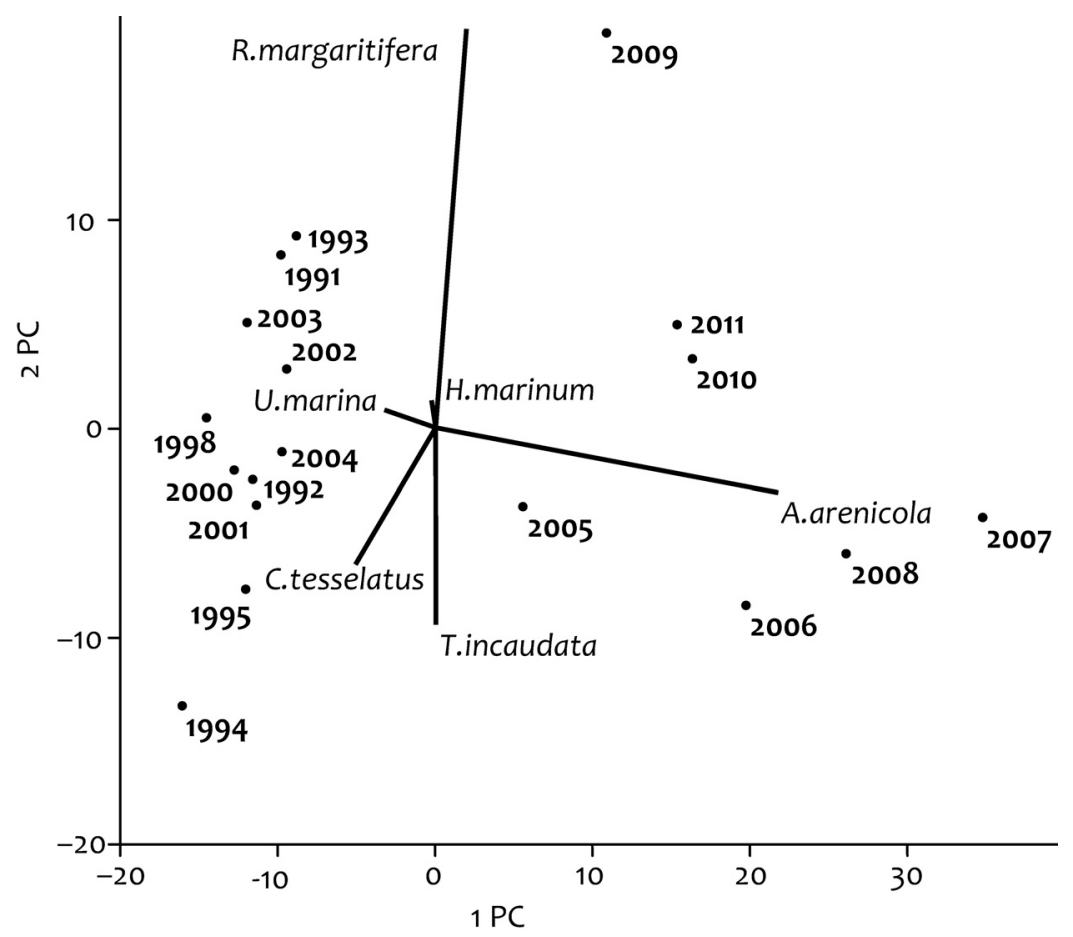

Fig. 3. Community ordination by principal component analysis based on relative abundances of first six dominant species (average for annual period). 1 PC - first principal component (explained $71.2 \%$ of the total community variance), 2 PC - second principal component (15.8\%) 
There is only one possible cause of the substantial changes in community structure, and this is a significant change in the environmental characteristics (detailed analysis is given in [9-12]). Since 1998, and particularly in 2005-2011 the siltation of the sediments grew considerably, decreasing the spaces of clean sand within the littoral. Siltation always leads to the decrease in the volume of interstitial spaces, the narrowing of the photic layer, the changes in the composition of the algal communities (the trend being from dinoflagellates to diatoms), the increasing amount of dead organic matter and the decrease in the oxygen content with the proportional increase in the concentration of carbon dioxide and hydrogen sulfide. As a result, the living space for oxyphilic organisms is reduced by several times. On the background of these interrelated changes, the abundance of eurytopic oxyphilic ciliate species (that are usually small-sized and feed on bacteria) decreased considerably during the last years, while the ratio of specific interstitial microaerophilic ciliates (that are predominantly medium to large-sized and feed on diatoms) correspondingly increased. Thus, both trophic and size structure were modified. The community of interstitial ciliates that in the first period of our investigation (1991-2005) was characterized by a multivectorial variation (within the indivisible pattern of community organization), starting from a concrete moment (2006) became canalized in terms of community structure changes (in accordance with the trends of modifications of the major properties at the ecosystem level).

\section{Annual cycle of the ciliate community}

Hereafter, we provide general verbal model of seasonal development of the ciliate community based on our previously published data $[4,5,10]$. It is necessary before starting to analyze long-term patterns of different seasonal community stages.

In the course of the year, the ciliate community passes through a complex cycle of structural and functional modifications. From late winter to early autumn, the community undergoes modification towards growing complexity. The cause of these processes is the fast increase in the energy (light and heat) input in the beginning of spring, when the intertidal flat is exposed after ice thawing (Table 2). The increase in the light flux and the heating of sediments up to $6-8{ }^{\circ} \mathrm{C}$ leads to a rapid increase in bacterial abundances (3-4 orders of magnitude), as well as in the increase in the abundance of the tiniest diatoms, dinoflagellates and heterotrophic flagellates (2-3 times), which are the main food for interstitial ciliates. These changes lead to a very fast growth of the abundance of some ciliate species: up to 2-3 times during 3-4 days. This is the beginning of the first stage of seasonal succession.

Table 2

Changes in the environmental variables and the ciliate community during cyclic seasonal succession in 2000-2001

\begin{tabular}{|c|c|c|c|c|c|c|c|}
\hline \multirow[b]{3}{*}{ Characteristics } & \multicolumn{7}{|c|}{ Time } \\
\hline & & & & $2000-2001$ & & & \\
\hline & $\begin{array}{c}\text { spring } \\
15 . \mathrm{V}-15 . \mathrm{VI}\end{array}$ & $\begin{array}{l}\text { summer } \\
\text { 16.VI-6.IX }\end{array}$ & $\begin{array}{c}\text { mid } \\
\text { of winter } \\
\text { 5.I-10.II }\end{array}$ & $\begin{array}{l}\text { end of winter } \\
25 . I V-29 . I V\end{array}$ & $\begin{array}{l}\text { beginning } \\
\text { of spring } \\
3 . \mathrm{V}-5 . \mathrm{V}\end{array}$ & \begin{tabular}{|c} 
spring \\
$13 . \mathrm{V}-15 . \mathrm{VI}$
\end{tabular} & $\begin{array}{l}\text { summer } \\
16 . \mathrm{VI}-5 . \mathrm{IX}\end{array}$ \\
\hline $\begin{array}{l}\text { Maximal light intensity } \\
\text { in the top } 1 \mathrm{~cm} \text { sediment } \\
\text { layer, lux }\end{array}$ & 18000 & 16000 & 400 & 800 & 17000 & 19000 & 17000 \\
\hline Temperature, ${ }^{\circ} \mathrm{C}$ & 11.2 & 15.7 & -0.5 & -0.5 & 6.0 & 8.7 & 17.3 \\
\hline Salinity, \%o & 10.3 & 19.7 & 22.1 & 22.6 & 8.1 & 10.4 & 19.2 \\
\hline $\begin{array}{l}\text { Number of ciliate species } \\
\text { in the community }\end{array}$ & 86 & 116 & 58 & 29 & 47 & 91 & 118 \\
\hline $\begin{array}{l}\text { Number of species } \\
\text { per sample }\end{array}$ & 46.3 & 49.7 & 42.3 & 8.2 & 32.0 & 48.1 & 63.2 \\
\hline Abundance, ind.$/ \mathrm{cm}^{2}$ & 813.8 & 1163.3 & 294.4 & 20.8 & 585.5 & 778.3 & 1240.1 \\
\hline Biomass, $\mathrm{mg} / \mathrm{m}^{2}$ & 148.9 & 268.7 & 75.4 & 4.8 & 76.5 & 186.7 & 365.8 \\
\hline $\begin{array}{l}\text { Average size } \\
\text { of the individual, } 10^{3} \mu \mathrm{m}\end{array}$ & 18.3 & 23.1 & 25.6 & 23.0 & 9.8 & 24.3 & 29.5 \\
\hline Main food of ciliates & $\mathrm{A}, \mathrm{B}, \mathrm{P}^{*}$ & $\mathrm{~A}, \mathrm{~B}, \mathrm{P}$ & $\mathrm{B}, \mathrm{P}, \mathrm{D}$ & DOM,D,B & $\mathrm{A}, \mathrm{B}$ & $\mathrm{A}, \mathrm{B}, \mathrm{P}$ & $\mathrm{A}, \mathrm{B}, \mathrm{P}$ \\
\hline $\begin{array}{l}\mathrm{CV}^{* *} \text { of the species } \\
\text { relative abundances, } \%\end{array}$ & 112.0 & 84.8 & 138.4 & 222.0 & 116.1 & 107.4 & 74.7 \\
\hline $\begin{array}{l}\text { Average rate of } \\
\text { community structure } \\
\text { changes per day, } \%\end{array}$ & - & 0.72 & 0.19 & 0.38 & 12.0 & 2.0 & 0.65 \\
\hline
\end{tabular}

* A - algae, $\mathrm{B}$ - bacteria, $\mathrm{P}$ - protozoa, D - detritus, DOM - dissolved organic matter.

** CV - variation coefficient. 
Species composition and structure could differ considerably in different areas of the intertidal flat. The basis of the community is formed by small size ciliates Uronema marina (or Cyclidium fuscum, Pleuronema coronata), Paradiophrys histrix (or Strombidium sulcatum, Strombidium viridae), Didinium balbiani (or Mesodinium pulex, Mesodinium pupula) and Coleps tesselatus (or Coleps pulcher, Coleps hirtus, Coleps similis, Plagiopogon loricatus). These ciliates constitute up to $90 \%$ of the total abundance and $60 \%$ of the biomass at the first stage. Trophic preferences of the dominant species are very different, and overlapping of trophic spectra are low (10-35\%). To illustrate, Uronema marina feed on bacteria, Diophrys histrix consume dinoflagellates, Mesodinim pulex capture heterotrophic nanoflagellates, while Coleps tesselatus prefer tissues of decaying multicellular organisms as well as particles of detritus.

The first stage of the seasonal succession is characterized by the maximal rates of community changes (up to $12 \%$ per day), which is 6-30 times higher than at the other stages of annual community transformation (Table 2). The evident cause of this is the high rate of reproduction of small ciliates, stimulated by the rapidly increasing temperature (from 0 to $10-12^{\circ} \mathrm{C}$ ), abundant food and minimal competition for resources from the ecologically close but larger ciliates that did not reach maximal summer abundances.

The second stage of seasonal succession lasts 4-6 weeks and is characterized by a marked increase in complexity due to a more even species distribution in the community and a more intense development of ciliates in deeper sediment layers (down to $0.5-2.0 \mathrm{~cm}$ ). Species richness, abundance and biomass increase considerably. The composition of dominants also changes. Species with high abundances are not only small-sized, but also medium-sized (20-60 thsd. $\mu \mathrm{m}^{3}$ : Lacrymaria spp., Diophrys scutum, Gastrostyla pulchra, Remanella spp., Histiobalantium spp., Trachelocercidae gnn., spp.) and even rather large (80-170 thsd. $\mu \mathrm{m}^{3}$ : Trachelocerca incaudata, Cardiostomatella vermiformis, Geleia fossata).

The food spectra of the newly appeared species overlap considerably with those of the species from the first succession stage (up to 60-90\%). At the same time, some of the newly appeared species could consume small ciliates that had been dominant during the first stage. As a result of predation and competition for food and space [3], the community structure continuously changed. The number of large ciliates with broad food spectra is increasing.

The trend towards increasing community complexity, outlined during the second stage, became more evident during the third stage (see Table 2: summer period). The composition of dominants remained the same, but ratio of species is modified. Variability of species abundances decreased. During this period, the community is characterized by the maximal values of total abundance, biomass and species richness. The set of dominant species included all size ranges and all trophic groups with a prominent leader: Trachelocerca incaudata, one of the largest interstitial ciliates, which formed in different years from 30 to $60 \%$ of the total community biomass. This is the most mature state of the community, with the highest complexity, the complementary trophic structure, the maximal assimilation of resources and the highest stability in space and time [5].

In autumn (September), the first signs of community simplification appear; in winter (December-April, the fourth stage of seasonal succession) they became more evident. The process of simplification proceeds rather slowly. In the middle of the winter (January-February), the community still maintains a moderate level of species richness, abundance and biomass (see Table 2); in general, the community maintains traits from the beginning of autumn (community similarity between September and January is 55-65\%). More than 60 species, from all size and trophic groups constantly lived in this period under the ice. Small and medium-sized ciliates (Histiobalantium marinum, Remanella margaritifera, Tracheloraphis kahli, Pleuronema coronata, Didinium balbiani, Uronema marina) were characterized by highest abundances. The number of species that feed on dinoflagellates and large diatoms decreases, but the number of ciliates feed on bacteria, debris, small diatoms and heterotrophic nanoflagellates increased.

At the end of the hydrological winter (MarchApril), the community is characterized by the simplest organization. It included solitary specimens of the most eurybiotic species that consume dissolved or particular organic matter: Uronema marina, Cyclidium fuscum, Aspidisca steini, Pleuronema coronata, Coleps tesselatus, Ciliofaurea sp., Histiobalantium marinum. The total abundance in the community is $3-4$ orders of magnitude lower than in summer. This is the end of the annual cycle of the community transformation (seasonal succession) that included two opposite trends: increasing complexity and stability from May to September and gradual regression from October to April.

\section{Long-term modifications of different stages of seasonal succession}

Delimitating of seasonal stages in the community development allows analyzing long-term trends separately for earlier (first) and most mature (third) stages of annual development. This allows addressing a 
general question: whether different stages of annual succession have different responses to the long-term environmental modifications occurred during 19912011. As shown in Figs. 4 and 5 the long-term patterns in case of different seasonal stages of ciliate community structure as well as the annually averaged data (see Figs. 2 and 3) reflect trended community transformation in course of twenty years.

Long-term pattern of $1^{\text {st }}$ stage of succession (Fig. 4) is subdivided into following groups. During 1991-1995 and 2000-2005 the 'typical' community structure (as it was described above in verbal model of seasonal succession) appeared. It was represented by nine, mostly small to medium size ciliates: Paradiophrys histrix, Remanella margaritifera, Uronema marina, Discocephalus rotatorius, Pleuronema coronata, Didinium balbiani, Coleps tesselatus, Uronema marina, Histiobalantium majus. High number of dominant species reflects high rates of community transformation, i.e. each week new species reaches high abundances. The specificity of $1^{\text {st }}$ stage in 1998 and 2009-2010 is determined by high abundance of medium size ciliate Hisitiobalantium marinum which accompanies by Apotrachelocerca arenicola in 2009-2010. Only later species dominates in 2006-2008 and 2011.
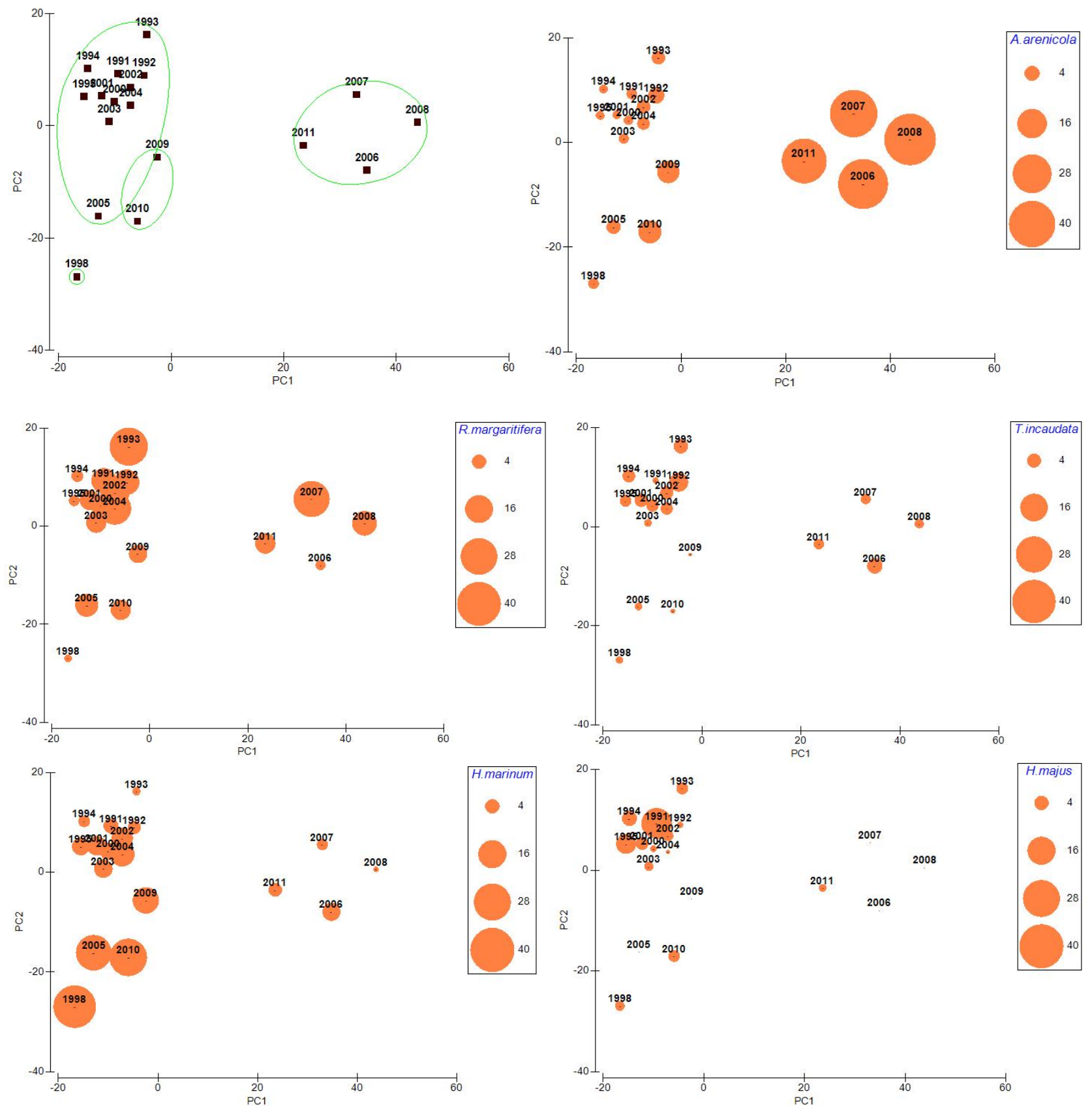

Fig. 4. Community ordination by principal component analysis based on relative abundances of all species in the community (average for the $1^{\text {st }}$ stage of annual succession). 1 PC - first principal component (explained $48.9 \%$ of the total community variance), 2 PC - second principal component (16.1\%).

Green lines encircle significant clusters segregated with the aid of SIMPROF algorithm of cluster analysis. Orange bubbles shows relative abundances of the dominant (represented more than $10 \%$ of the total community abundance at the $1^{\text {st }}$ stage of annual succession at least ones during the investigated period) species (first part) 

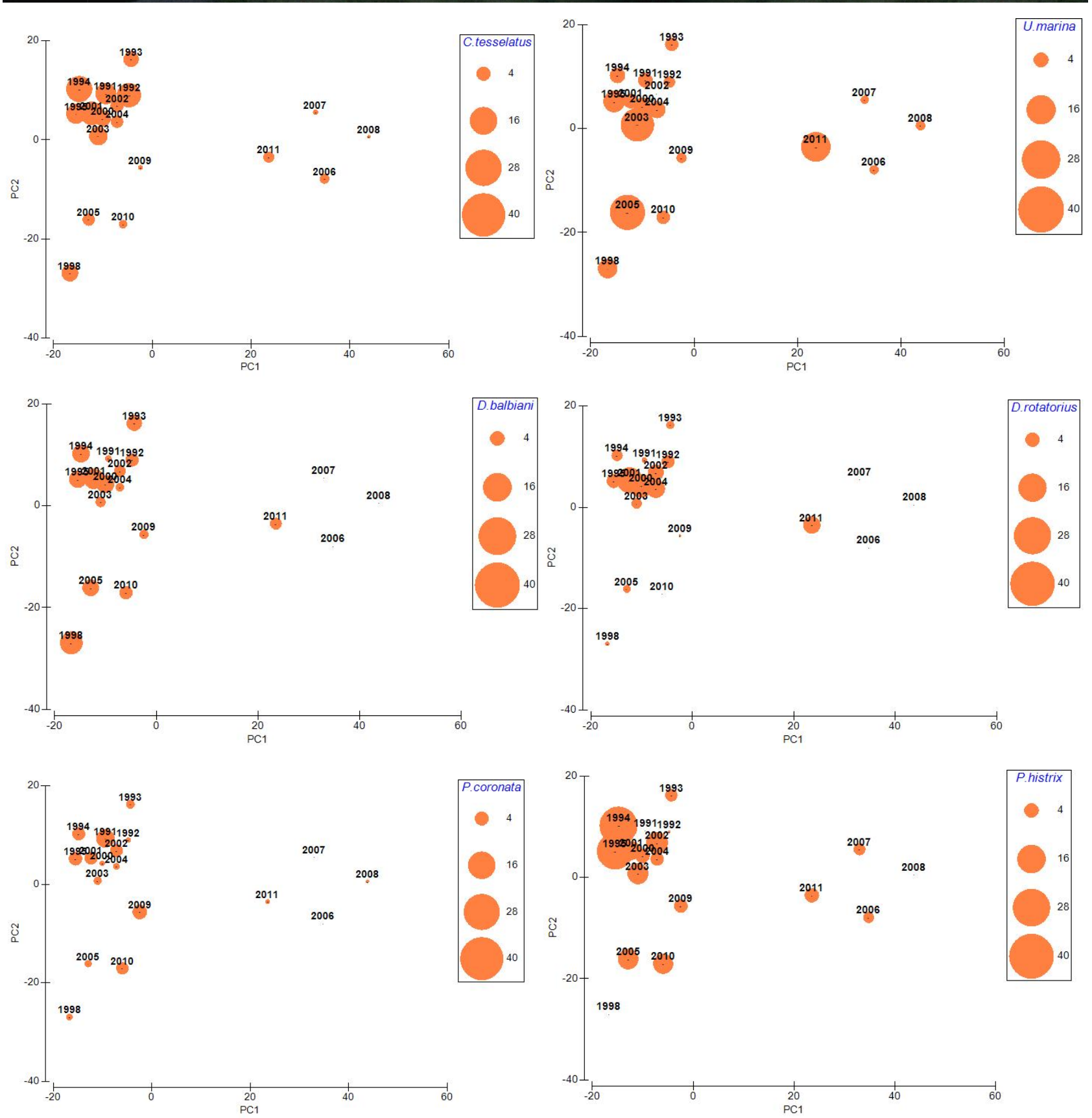

Fig. 4 (second part)

Long-term pattern of $3^{\text {rd }}$ stage of succession (see Fig. 5) is subdivided into following groups. The set of dominant species during 1991-2002 and 2004 was represented by Trachelocerca incaudata, Remanella margaritifera, Histiobalantium majus, Histiobalantium marinum, Coleps tesselatus, and Uronema marina. Only three species dominated in 2003 and 2005-2011: Apotrachelocerca arenicola, Trachelocerca incaudata, Remanella margaritifera.

Summing up, the distinct shift in community composition at $3^{\text {rd }}$ stage of succession occurred in 2003-2005, whereas it happened later, in 20052006 , at $1^{\text {st }}$ stage and was not so distinctive (the community turned back in 2009-2010). Most substantial modification in the community composi- tion was the appearance of a new dominant Apotrachelocerca arenicola, which had never been abundant previously. This species settled from 2006 at $3^{\text {rd }}$ stage of community succession and dominated at certain years (2006-2008 and 2011) at the $1^{\text {st }}$ one. This fact supports the idea that the most mature state of ciliate community (i.e. $3^{\text {rd }}$ stage of annual succession) is temporally (in the inter-year scale) stable and discretely transformed from one variant to another one. On the other hand, more simple state of ciliate community (i.e. $1^{\text {st }}$ stage) is more variable between years and transforms from one variant to another one more gradually. In another view, it means that discrete and stable mature communities are assembled via different annual trajectories. 

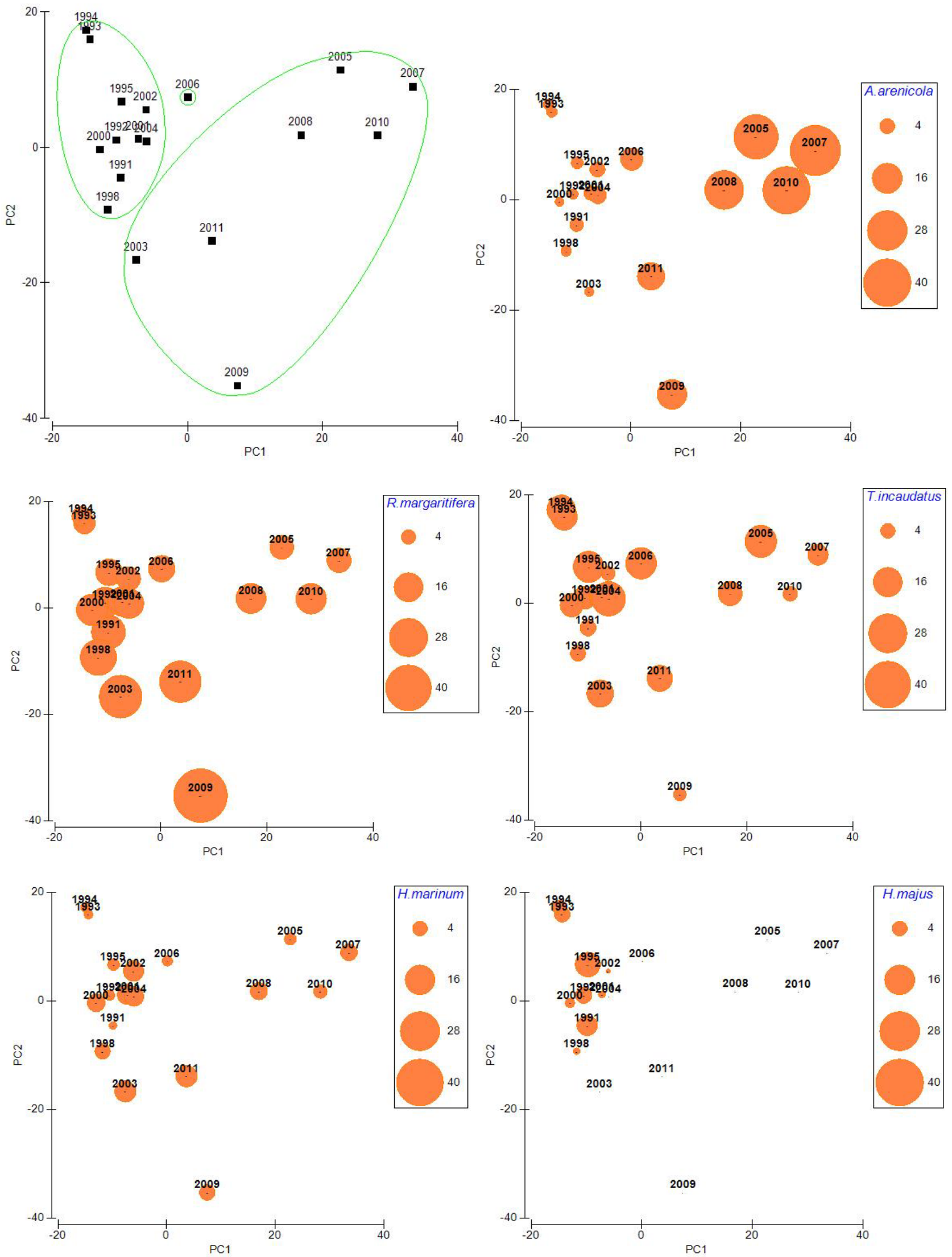

Fig. 5. Community ordination by principal component analysis based on relative abundances of all species in the community (average for the $3^{\text {rd }}$ stage of annual succession). 1 PC - first principal component

(explained $40.0 \%$ of the total community variance), 2 PC - second principal component (27.1\%).

Green lines encircle significant clusters segregated with the aid of SIMPROF algorithm of cluster analysis. Orange bubbles shows relative abundances of the dominant (represented more than $10 \%$ of the total community abundance at the $3^{\text {rd }}$ stage of annual succession at least ones during the investigated period) species (first part) 

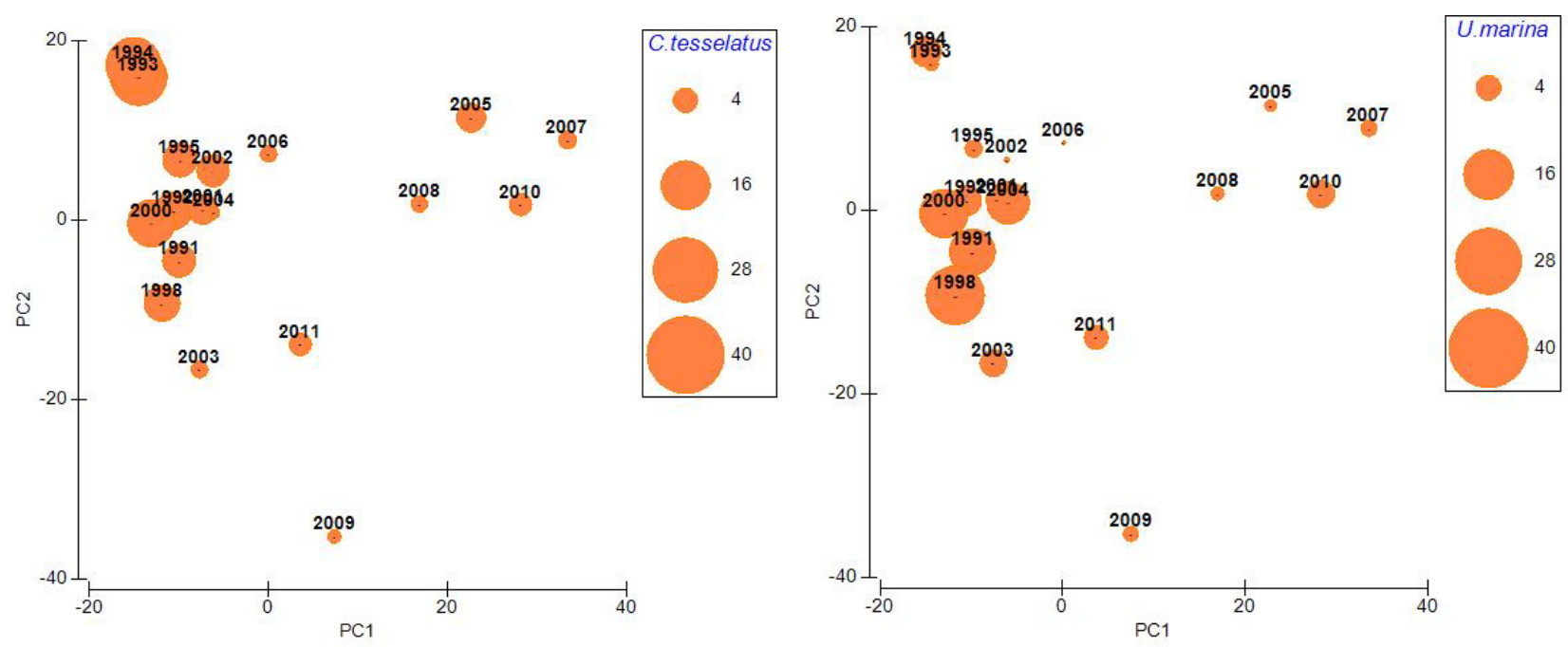

Fig. 5 (second part)

\section{Discussion}

Unfortunately, there are no other investigations of the long-term dynamics of recent protozoan communities (both aquatic and terrestrial), and so possibilities for direct comparison are scarce. There were, however, some examples of describing long-term variability of the invertebrates' communities in marine habitats.

Coull [15] studied the dynamics of total abundance and taxonomic composition of meiobenthic community on silty and sandy sediments in an estuary (North Inlet, South Carolina) for 11 years. Similarly to our case, he revealed substantial inter year fluctuations and a weak rhythm, which were in some cases correlated with salinity, temperature, Eh and granulometric structure of the sediment. Studies of the long-term changes in marine macrobenthic communities demonstrated prominent modifications caused by long-term environmental influence. For example, an evidence was found for a progressive trend in deep-ocean ecosystems that could be potentially linked to recent climate change [18]. Long-term research in the Baltic Sea revealed the basic trends of zooplankton community variations depending on oceanographic processes [1]. In the 1990s-2000s, the abundance and biomass of brackish-water and thermophilous species primarily of Cladocera and Copepoda increased markedly. The abundance of the previously dominant marine copepod decreased due to salinity reduction in the deep-water part of the Baltic Sea. Maximum development of zooplankton occurred in years of the greatest warming-up of the water $(2001,2005-2007)$ against the background of a general positive trend of zooplankton abundance in the last decade. Changes in the macrofauna of the sub-halocline bottoms of the Eastern Gotland Basin and the Gulf of Finland during the
1965-1994 period were detected in relation to the salinity and oxygen regimes [28]. The study period covered several significant major inflows of North Sea water, as well as the longest stagnation period during the last hundred years, with semi-permanent anoxia affecting the distribution and community structure of the macrozoobenthos. Investigation of the fish and macro-crustacean community of the Vaccares lagoon (Rhone River delta, South France) shows that community changes following environmental variations first of all salinity that shifted from $15 \%$ in 1993 to $5 \%$ in 1994-1997 and went back to $15 \%$ in 1999-2002.

In the White Sea, a number of long-term investigations of marine ecosystems were performed at three permanent biological stations operating in the Kandalaksha Gulf: those belonging to Lomonosov Moscow State University since 1938, Zoological Institute of the Russian Academy of Sciences since 1957, and Saint-Petersburg State University since 1974 [40]. A broad range of biological phenomena and processes were detected through the long-term regular studies and presented recently in a special volume of Hydrobiologia [40]. Monitoring of zooplankton communities indicated that besides the weak trend of long-term warming of the surface $(<70 \mathrm{~m})$ waters of the White Sea, the onset of hydrological summer in the upper water layers has shifted about 20 days earlier in the last 50 years. The "cold-water" zooplankton species appeared to be affected by these changes to a greater extent than the "warm-water" ones [42]. Rare extreme events such as abnormally cold or warm years and/or ice scouring of the soft sediments in the intertidal zone are followed by a relatively fast recovery of the pelagic and benthic communities $[35,42]$. In contrast, it takes years for subtidal benthic communities to recover from the impacts of the organic enrichment from the mussel aquacul- 
ture [23]. Many populations and benthic assemblages have shown temporal instability of population structure, abundance, species composition and other key characteristics. This instability is manifested as intrinsic cyclic oscillations or random fluctuations depending on interspecific $[25,26]$ and intraspecific $[17,25]$ interactions, resource depletion [27], sediment changes [39, 46], parasite influence [19], or random events [26, 30]. Special attention was also paid to the long-term patterns of spatial distribution in marine microbenthic assemblages [43]. It was shown that the assemblages were more variable at small scales and more stable at larger scales. Our results, concerning long-term patterns in different stages of the community annual development, indicate the importance of seasonal succession as a significant phenomenon determining mechanisms of the long term-community transformation.

All the cases described above link long-term community modifications with environmental changes. It was underlined [38] that all ecosystems are exposed to gradual changes in climate, nutrient loading, habitat fragmentation or biotic exploitation. Theoretically, biotic communities can respond to these environmental changes either in a smooth way or as a sudden drastic switch to a contrasting state [22, 31]. However, this is a nontrivial task, how to proof the multiplicity of stable states [13, 24, 38]. Schefter et al. [38] listed some consistent patterns to describe the shifts between different stable states of ecological systems.

"First, the contrast among states in ecosystems is usually due to a shift in dominance among organisms with different life forms" [38, p. 595]. In our case community from multi-dominant state represented by ciliates of different life forms (including both "elongated" interstitial dwellers sliding on the surface of sand grains and "oval" freemovers swimming in the spaces between sediment particles) turned to single-dominant state with dominance of specific "elongated" interstitial forms.

"Second, state shifts are usually triggered by obvious stochastic events such as pathogen outbreaks, fires or climate extremes" [38, p. 595]. In our case, the shift was triggered by the siltation of the sediment which is a result of the transformation of whole coastal ecosystem illustrated in detail in our previous publications $[9,10,11,12]$.

"Third, feedbacks that stabilize different states involve both biological and physical and chemical mechanisms" [38, p. 595]. Due to the fact (revealed in this study) that two different 'mature' seasonal states of ciliate community (shifted from one to another during 2003-2005) are assembled via seasonally different trajectories (i.e. 'simple' initial seasonal states have no distinct trend in long-term scale), we can assume, that some feedbacks including probably both biological and environmental interaction are involved in stabilizing 'mature' seasonal states of ciliate community.

\section{Acknowledgements}

The authors thank Dr. Alexey Tiunov for his valuable comments on the earlier variants of the manuscript. The work was supported by the grant of the Russian Foundation for Basic Research (grant No 16-04-00803).

\section{References}

1. Aleksandrov, S. V. Long-term dynamics of zooplankton in the southeastern Baltic Sea / S. V. Aleksandrov, N. N. Zhigalova, A. S. Zezera // Russian Journal of Marine Biology. - 2009. - Vol. 35, issue 4. - P. 296-304.

2. Burkovsky, I. V. The ecology of free-living ciliates / I. V. Burkovsky. - Moscow : Moscow State Univ. Press, 1984.

3. Burkovsky, I. V. Structural and functional organization and stability of marine benthic communities / I. V. Burkovsky. - Moscow : Moscow State Univ. Press, 1992.

4. Burkovsky, I. V. Marine biogeocoenology. Oganization of communities and ecosystems / I. V. Burkovsky. - Moscow : KMK Sci. Press, 2006.

5. Burkovsky, I. V. Annual cyclic changes and processes of self-organization in a marine microbenthic communities / I. V. Burkovsky, M. Yu. Kolobov, A. P. Stolyarov // Zhurnal Obshchei Biologii. - 2003. - Vol. 64. - P. 389-402.

6. Burkovsky, I. V. Initiation of processes of self-organization in marine microbenthic communities by extreme concentrations of biogenic elements / I. V. Burkovsky, M. Yu. Kolobov, A. P. Stolyarov // Zhurnal Obshchei Biologii. 2004. - Vol. 65. - P. 464-478.

7. Burkovsky, I. V. Structural and functional differentiation and integration in marine coastal ecosystem / I. V. Burkovsky, A. P. Stolyarov // Uspekhi Sovremennoi Biologii. - 2000 - Vol. 120. - P. 433-440.

8. Burkovsky, I. V. Ciliate community structure in the zone of mixing of sea and river waters / I. V. Burkovsky, Yu. A. Mazei // Zoologicheskii Zhurnal. - 2001. - Vol. 80, issue 3. - P. 267-268.

9. Burkovsky, I. V. Changes in the structure of marine psammophilous ciliate communities for the time period characteristic of thousands generations / I. V. Burkovsky, Yu. A. Mazei // Uspekhi Sovremennoi Biologii. - 2008. Vol. 128, issue 4. - P. 384-399.

10. Burkovsky, I. V. Interannual variability of seasonal succession in psammophilous ciliate community in the White Sea / I. V. Burkovsky, Yu. A. Mazei // Uspekhi Sovremennoi Biologii. - 2008. - Vol. 128, issue 6. - P. 562-579. 
11. Burkovsky, I. V. Long-term dynamics of marine interstitial ciliate community / I. V. Burkovsky, Yu. A. Mazei // Protistology. - 2010. - Vol. 6, issue 3. - P. 147-172.

12. Burkovsky, I. V. Long-term changes of psammophilous ciliate populations in the White Sea / I. V. Burkovsky, Yu. A. Mazei // Uspekhi Sovremennoi Biologii. - 2010. - Vol. 130, issue 2. - P. 200-215.

13. Carpenter, S. R. Dystrophy and eutrophy in lake ecosystems: implications of fluctuating inputs / S. R. Carpenter, M. L. Pace // Oikos. - 1997. - Vol. 78. - P. 3-14.

14. Clarke, K. Change in Marine Communities: An Approach to Statistical Analysis and Interpretation / K. Clarke, R. Warwick. - 2nd ed. - PRIMER_E, Plymouth, 2001.

15. Coull, B. C. Long-term variability of estuarine meiobenthos: an 11-year study / B. C. Coull // Marine Ecology Progress Series. - 1985. - Vol. 24. - P. 205-218.

16. Fenchel, T. The ecology of marine microbenthos. IV. Structure and function of the benthic ecosystem, its chemical and physical factors and the microfauna communities with the special reference to the ciliated protozoa / T. Fenchel // Ophelia. - 1969. - Vol. 6. - P. 1-182.

17. Gerasimova, A. V. Age-size structure of common bivalve mollusc populations in the White Sea: the causes of instability / A. V. Gerasimova, N. V. Maximovich // Hydrobiologia. - 2013. - Vol. 706. - P. 119-137.

18. Temporal change in deep sea benthic ecosystems: a review of the evidence from recent time series studies $/$ A. G. Glover, A. J. Gooday, D. M. Bailey, D. S. M. Billett, P. Chevaldonne, A. Colaco, J. Copley, D. Cuvelier, D. Desbruyeresk, V. Kalogeropoulou, M. Klages, N. Lampadariou, C. Lejeusne, N. C. Mestre, G. L. J. Paterson, T. Perez, H. Ruhl, J. Sarrazin, T. Soltwedel, E. H. Soto, S. Thatje, A. Tselepides, S. Van Gaever, A. Vanreusel // Advances in Marine Ecology. - 2010. - Vol. 58. - P. 1-95.

19. Granovitch, A. I. Long-term population dynamics of Littorina obtusata: the spatial structure and impact of trematodes / A. I. Granovitch, A. N. Maximovich // Hydrobiologia. - 2013. - Vol. 706. - P. 91-101.

20. Hammer, O. PAST: Palaeontological Statistics software package for education and data analysis / O. Hammer, D. A. T. Harper, P. D. Ryan // Palaeontologica electronica. - 2001. - Vol. 4, issue 1. - P. 1-9.

21. Harris, R. P. Seasonal changes in the meiofauna population of an intertidal sand beach / R. P. Harris // Journal of Marine Biological Association of UK. - 1972. - Vol. 52. - P. 389-403.

22. Holling, C. S. Resilience and stability of ecological systems / C. S. Holling // Annual Review of Ecology and Systematics. - 1973. - Vol. 4. - P. 1-23.

23. Degradation and recovery of an Arctic benthic community under organic enrichment / M. V. Ivanov, D. S. Smagina, S. M. Chivilev, O. E. Kruglikov // Hydrobiologia. - 2013. - Vol. 706. - P. 191-204.

24. Ives, A. R. Complex dynamics in stochastic tritrophic models / A. R. Ives, V. A. A. Jansen // Ecology. - 1998. Vol. 79. - P. 1039-1052.

25. Khaitov, V. Life in an unstable house: community dynamics in changing mussel beds / V. Khaitov // Hydrobiologia. 2013. - Vol. 706. - P. 139-158.

26. Khalaman, V. V. Regular and irregular events in fouling communities in the White Sea / V. V. Khalaman // Hydrobiologia. - 2013. - Vol. 706. - P. 205-219.

27. Kozminsky, E. V. Effects of environmental and biotic factors on the fluctuations of abundance of Littorina obtusata (Gastropoda: Littorinidae) / E. V. Kozminsky // Hydrobiologia. - 2013. - Vol. 706. - P. 81-90.

28. Long-term changes of macrozoobenthos in the Eastern Gotland Basin and the Gulf of Finland (Baltic Sea) in relation to the hydrographical regime / A. O. Laine, H. Sandier, A.-B. Andersin, J. Stigzelius // Journal of Sea Research. 1997. - Vol. 38. - P. 135-159.

29. Long-term datasets in biodiversity research and monitoring: assessing change in ecological communities through time / A. E. Magurran, S. R. Baillie, S. T. Buckland, J. P. Mc Dick, D. A. Elston, M. E. Scott, R. I. Smith, P. J. Somerfield, A. D. Watt // Trends in Ecology and Evolution. - 2010. - Vol. 25. - P. 574-582.

30. Marfenin, N. N. Fluctuations in settlement and survival of a barnacle Semibalanus balanoides at the White Sea intertidal / N. N. Marfenin, F. Bolshakov, M. Mardashova // Hydrobiologia. - 2013. - Vol. 706. - P. 51-68.

31. May, R. M. Thresholds and breakpoints in ecosystems with a multiplicity of stable states / R. M. May // Nature. 1977. - Vol. 269. - P. 471-477.

32. Mazei, Yu. A. Species composition of benthic ciliate community in the Chernaya river estuary (Kandalaksha gulf, White Sea) with a checklist of total White Sea benthic ciliate fauna / Yu. A. Mazei, I. V. Burkovsky // Protistology. 2005. - Vol. 4. - P. 107-120.

33. Mazei, Yu. A. Patterns of psammophilous ciliate community structure along salinity gradient in the White Sea estuary / Yu. A. Mazei, I. V. Burkovsky // Protistology. - 2006. - Vol. 4. - P. 251-268.

34. Seasonal and interannual dynamics of microzooplankton abundances in the Gulf of Trieste (Northern Adriatic Sea, Italy) / M. Monti, M. Minocci, L. Milani, S. F. Umani // Estuarine, Coastal and Shelf Science. - 2012. - Vol. 115. P. 149-157.

35. Naumov, A. D. Long-term fluctuations of soft-bottom intertidal community structure affected by ice cover at two small sea bights in the Chupa Inlet (Kandalaksha Bay) of the White Sea / A. D. Naumov // Hydrobiologia. - 2013. Vol. 706. - P. 159-173.

36. Patterson, D. J. The ecology of heterotrophic flagellates and ciliates living in marine sediments / D. J. Patterson, J. Larsen, J. O. Corliss // Progress in Protistology. - 1989. - Vol. 3. - P. 185-277.

37. Long-term fish and macro-crustacean community variation in a Mediterranean lagoon / G. Poizat, E. Rosecchi, Ph. Chauvelon, P. Contournet, A. J. Crivelli // Estuarine, Coastal and Shelf Science. - 2004. - Vol. 59. - P. 615624. 
38. Catastrophic shifts in ecosystems / M. Scheffer, S. Carpenter, J. A. Foley, C. Folke, B. Walker // Nature. - 2001. Vol. 413. - P. 591-596.

39. Skazina, M. Paving the way for the new generations: Astarte borealis population dynamics in the White Sea / M. Skazina, E. Sofronova, V. Khaitov // Hydrobiologia. - 2013. - Vol. 706. - P. 35-49.

40. Sukhotin, A. Long-term monitoring studies as a powerful tool in marine ecosystem research / A. Sukhotin, V. Berger // Hydrobiologia. - 2013. - Vol. 706. - P. 1-9.

41. Uhlig, G. Eine einfache Methode zur Extraktion der vagilen mesopsammalen Mikrofauna / G. Uhlig // Helgollander Wissenshaft Meeresuntersuchungen. - 1964. - Bd. 11. - S. 178-185.

42. Every species is good in its season: do the shifts in the annual temperature dynamics affect the phenology of the zooplankton species in the White Sea? / N. Usov, I. Kutcheva, I. Primakov, D. Martynova // Hydrobiologia. - 2013. Vol. 706. - P. 11-33.

43. Varfolomeeva, M. Long-term temporal and spatial variation of macrobenthos in the intertidal softbottom flats of two small bights (Chupa Inlet, Kandalaksha Bay, White Sea) / M. Varfolomeeva, A. Naumov // Hydrobiologia. - 2013. Vol. 706. - P. 175-189.

44. Climate scaling behavior in the dynamics of the marine interstitial ciliate community / C. A. Varotsos, Yu. A. Mazei, I. V. Burkovsky, M. N. Efstathiou, Ch. G. Tzanis // Theoretical and Applied Climatology. - 2016. Vol. 125. - P. 439-447.

45. Long-term phytoplankton community dynamics in the Western English Channel / C. E. Widdicombe, D. Eloire, D. Harbour, R. P. Harris, P. J. Somerfield // Journal of Plankton Resaerch. - 2010. - Vol. 32. - P. $643-655$.

46. Synchronous annual recruitment variation in barnacles and ascidians in the White Sea shallow subtidal 1999-2010/ E. L. Yakovis, A. V. Artemieva, M. V. Fokin, M. A. Varfolomeeva, N. N. Shunatova // Hydrobiologia. - 2013. Vol. 706. - P. 69-79.

\section{References}

1. Aleksandrov S. V., Zhigalova N. N., Zezera A. S. Russian Journal of Marine Biology. 2009, vol. 35, issue 4, pp. 296-304.

2. Burkovsky I. V. The ecology of free-living ciliates. Moscow: Moscow State Univ. Press, 1984.

3. Burkovsky I. V. Structural and functional organization and stability of marine benthic communities. Moscow: Moscow State Univ. Press, 1992.

4. Burkovsky I. V. Marine biogeocoenology. Oganization of communities and ecosystems. Moscow: KMK Sci. Press, 2006.

5. Burkovsky I. V., Kolobov M. Yu., Stolyarov A. P. Zhurnal Obshchei Biologii [Journal of General Biology]. 2003, vol. 64, pp. 389-402.

6. Burkovsky I. V., Kolobov M. Yu., Stolyarov A. P. Zhurnal Obshchei Biologii [Journal of General Biology]. 2004, vol. 65, pp. 464-478.

7. Burkovsky I. V., Stolyarov A. P. Uspekhi Sovremennoi Biologii [Advances in Modern Biology]. 2000, vol. 120, pp. 433-440.

8. Burkovsky I. V., Mazei Yu. A. Zoologicheskii Zhurnal [Zoological journal]. 2001, vol. 80, issue 3, pp. $267-268$.

9. Burkovsky I. V., Mazei Yu. A. Uspekhi Sovremennoi Biologii [Advances in Modern Biology]. 2008, vol. 128, issue 4, pp. 384-399.

10. Burkovsky I. V., Mazei Yu. A. Uspekhi Sovremennoi Biologii [Advances in Modern Biology]. 2008, vol. 128, issue 6 , pp. 562-579.

11. Burkovsky I. V., Mazei Yu. A. Protistology. 2010, vol. 6, issue 3, pp. 147-172.

12. Burkovsky I. V., Mazei Yu. A. Uspekhi Sovremennoi Biologii [Advances in Modern Biology]. 2010, vol. 130, issue 2, pp. 200-215.

13. Carpenter S. R., Pace M. L. Oikos. 1997, vol. 78, pp. 3-14.

14. Clarke K., Warwick R. Change in Marine Communities: An Approach to Statistical Analysis and Interpretation. 2nd ed. PRIMER_E, Plymouth, 2001.

15. Coull B. C. Marine Ecology Progress Series. 1985, vol. 24, pp. 205-218.

16. Fenchel T. Ophelia. 1969, vol. 6, pp. 1-182.

17. Gerasimova A. V., Maximovich N. V. Hydrobiologia. 2013, vol. 706, pp. 119-137.

18. Glover A. G., Gooday A. J., Bailey D. M., Billett D. S. M., Chevaldonne P., Colaco A., Copley J., Cuvelier D., Desbruyeresk D., Kalogeropoulou V., Klages M., Lampadariou N., Lejeusne C., Mestre N. C., Paterson G. L. J., Perez T., Ruhl H., Sarrazin J., Soltwedel T., Soto E. H., Thatje S., Tselepides A., Van Gaever S., Vanreusel A. Advances in Marine Ecology. 2010, vol. 58, pp. 1-95.

19. Granovitch A. I., Maximovich A. N. Hydrobiologia. 2013, vol. 706, pp. 91-101.

20. Hammer O., Harper D. A. T., Ryan P. D. Palaeontologica electronica. 2001, vol. 4, issue 1, pp. 1-9.

21. Harris R. P. Journal of Marine Biological Association of UK. 1972, vol. 52, pp. 389-403.

22. Holling C. S. Annual Review of Ecology and Systematics. 1973, vol. 4, pp. 1-23.

23. Ivanov M. V., Smagina D. S., Chivilev S. M., Kruglikov O. E. Hydrobiologia. 2013, vol. 706, pp. $191-204$.

24. Ives A. R., Jansen V. A. A. Ecology. 1998, vol. 79, pp. 1039-1052.

25. Khaitov V. Hydrobiologia. 2013, vol. 706, pp. 139-158. 
26. Khalaman V. V. Hydrobiologia. 2013, vol. 706, pp. 205-219.

27. Kozminsky E. V. Hydrobiologia. 2013, vol. 706, pp. 81-90.

28. Laine A. O., Sandier H., Andersin A.-B., Stigzelius J. Journal of Sea Research. 1997, vol. 38, pp. $135-159$.

29. Magurran A. E., Baillie S. R., Buckland S. T., Mc Dick J. P., Elston D. A., Scott M. E., Smith R. I., Somerfield P. J., Watt A. D. Trends in Ecology and Evolution. 2010, vol. 25, pp. 574-582.

30. Marfenin N. N., Bolshakov F., Mardashova M. Hydrobiologia. 2013, vol. 706, pp. 51-68.

31. May R. M. Nature. 1977, vol. 269, pp. 471-477.

32. Mazei Yu. A., Burkovsky I. V. Protistology. 2005, vol. 4, pp. 107-120.

33. Mazei Yu. A., Burkovsky I. V. Protistology. 2006, vol. 4, pp. 251-268.

34. Monti M., Minocci M., Milani L., Umani S. F. Estuarine, Coastal and Shelf Science. 2012, vol. 115, pp. $149-157$.

35. Naumov A. D. Hydrobiologia. 2013, vol. 706, pp. 159-173.

36. Patterson D. J., Larsen J., Corliss J. O. Progress in Protistology. 1989, vol. 3, pp. 185-277.

37. Poizat G., Rosecchi E., Chauvelon Ph., Contournet P., Crivelli A. J. Estuarine, Coastal and Shelf Science. 2004, vol. 59, pp. 615-624.

38. Scheffer M., Carpenter S., Foley J. A., Folke C., Walker B. Nature. 2001, vol. 413, pp. 591-596.

39. Skazina M., Sofronova E., Khaitov V. Hydrobiologia. 2013, vol. 706, pp. 35-49.

40. Sukhotin A., Berger V. Hydrobiologia. 2013, vol. 706, pp. 1-9.

41. Uhlig G. Helgollander Wissenshaft Meeresuntersuchungen [Marine research of Heligoland]. 1964, vol. 11, pp. 178185.

42. Usov N., Kutcheva I., Primakov I., Martynova D. Hydrobiologia. 2013, vol. 706, pp. 11-33.

43. Varfolomeeva M., Naumov A. Hydrobiologia. 2013, vol. 706, pp. 175-189.

44. Varotsos C. A., Mazei Yu. A., Burkovsky I. V., Efstathiou M. N., Tzanis Ch. G. Theoretical and Applied Climatology. 2016, vol. 125, pp. 439-447.

45. Widdicombe C. E., Eloire D., Harbour D., Harris R. P., Somerfield P. J. Journal of Plankton Resaerch. 2010 , vol. 32, pp. 643-655.

46. Yakovis E. L., Artemieva A. V., Fokin M. V., Varfolomeeva M. A., Shunatova N. N. Hydrobiologia. 2013 , vol. 706, pp. 69-79. 